\title{
ANALISIS TENTANG TANGGUNG JAWAB PT. GHALAZ SUKSES PERKASA BANDAR LAMPUNG TERKAIT WANPRESTASI DALAM PERJANJIAN JUAL BELI PERUMAHAN (Studi Putusan Nomor 02/PDT.G/2018/PN.TJK)
}

\author{
Oleh \\ ISWAHYUDI $^{1}$, APRILLIANTI ${ }^{2}$, YULI ERNITASARI ${ }^{3}$ \\ Fakultas Hukum Universitas Bandar Lampung \\ Jl. ZA Pagar Alam No 26 Labuhan Ratu Bandar Lampung
}

Email: yudi87424@gmail.com; aprillianti@ubl.ac.id; yuli.ernitasari@ubl.ac.id

\begin{abstract}
ABSTRAK
An agreement is a legal act whereby a person promises to another person or where the two men promise each other to carry out an agreement. The problems in this research is whether the factors causing default in the PT. Ghalaz Sukses Perkasa Bandar Lampung against creditors, how is the responsibility and implementation of their rights and obligations. The research method used a normative and empirical juridical approach, the data used are secondary data and primary data. Studies conducted with literature studies and field studies, data analysis used is qualitative juridical. Based on the results of the study it can be seen that Factors that cause Defaults are caused by the intentions or negligence of the debtor itself, this intentional element arises from the party itself. Factors that are general in nature, undisciplined so that they carry out these achievements when they expire, underestimate the agreement. Accountability of PT. Ghalaz Sukses Perkasa Bandar Lampung against creditors based on decision Number 02 / Pdt.G / 2018 / PN.Tjk in the consideration of the assembly the intent and purpose of the plaintiff's claim is basically Default. Where the previous defendant agreed to return the booking fee / down payment / home installments, the implementation of the rights and obligations of PT. Ghalaz Sukses Perkasa Bandar Lampung against creditors based on decision Number 02/Pdt.G/2018/PN.Tjk, the creditor must prove as much as possible that his opponent (debtor) has defaulted, not overmacht.
\end{abstract}

Keywords: accountability, default, sale and purchase agreement, housing.

\section{PENDAHULUAN}

Indonesia adalah Negara yang berdasarkan hukum atau juga disebut Negara hukum. Sebagai yang diatur dalam Pasal 1 ayat (3) Undang-undang Dasar 1945 yaitu Negara Indonesia adalah Negara hukum, jo Pasal 27 ayat (1) Undang-undang dasar 1945 yaitu segala warga Negara Indonesia bersamaan kedudukanya didalam hukum dan pemerintahan itu dengan tidak ada kecualian, jo pasal 28D yaitu setiap orang berhak atas pengakuan, jaminan, dan kepastian hukum yang adil serta perlakuan yang sama di hadapan hukum Undangundang Dasar 1945. Kebutuhan manusia satu dan manusia lainnya berbeda sesuai usia dan status sosialnya. Dahulu kala, orang melakukan perikatan dengan yang lain guna memenuhi kebutuhan hidupnya dengan cara barter (penukaran barang dengan barang), lalu berubah menjadi penukaran barang dengan uang.

Menurut Yahya Harahap (1986:4) Perjanjian adalah suatu perbuatan hukum dimana seorang berjanji kepada seorang lain atau dimana kedua orang itu saling berjanji untuk melaksanakan suatu hal (Menurut pasal 1313 KUHPerdata), pengertian perjanjian ini hanya terletak dalam lapangan harta kekayaan, artinya sesuatu yang dapat dinilai dengan uang. Perjanjian merupakan salah satu sumber perikatan,diatur dalam buku III 
KUHPerdata yang berjudul tentang perikatan (Van verbintenis). perjanjian merupakan terjemahan dari bahasa Belanda yaitu Oveerencomsten, dan kadang kala diterjemahkan sebagai persetujuan. sedangkan Perikatan berasal dari bahasa Belanda yaitu Verbintenis yang kadang kala diterjemahkan dengan perutangan, Perikatan (verbintenis) adalah suatu perhubungan hukum antara dua pihak dalam lapangan harta benda,dimana pihak yang satu berhak menuntut sesuatu dari pihak yang lain,dan pihak yang lainnya berkewajiban untuk memenuhi apa yang dituntut pihak lain.

Istilah perjanjian dalam hukum perjanjian merupakan kesepadanan dari istilah overeenkomst dalam bahasa belanda atau Agreement dalam bahasa inggris. Karena itu istilah hukum perjanjian mempunyai cakupan yang lebih sempit dari hukum perikatan Perjanjian adalah suatu kesepakatan yang di perjanjikan (promissory agreement) di antara dua atau lebih pihak yang dapat memberikan modifikasi, atau menghilangkan hubungan hukum.

Seringnya hal-hal yang menjadi persoalan dalam hukum perjanjian adalah pengingkaran atau kelalaian seorang debitur kepada kreditur, atau pemenuhan janji yang dilakukan oleh debitur. Dalam hukum perdata, keduanya disebut dengan prestasi bagi yang memenuhi janji dan wanprestasi bagi yang tidak memenuhi janji. Riduan Syahrani dalam (Tami Rusli, 2012:37-40) mendefinisikan bahwa prestasi adalah suatu yang wajib dan harus dipenuhi oleh debitur dalam setiap perikatan.

Prestasi adalah sesuatu yang wajib dipenuhi oleh debitur dalam setiap perikatan. Prestasi adalah objek perikatan, sehingga dalam hukum perdata kewajiban memenuhi prestasi selalu disertai jaminan harta kekayaan debitur. Pasal 1131 dan 1132 KUHPerdata dinyatakan bahwa harta kekayaan debitur, baik yang bergerak maupun yang tidak bergerak, baik yang sudah ada maupun yang akan ada, menjadi jaminan pemenuhan utangnya terhadap kreditur. Namun, jaminan umum tersebut dapat dibatasi dengan jaminan khusus berupa benda tertentu yang ditetapkan dalam perjanjian antar pihak.

Sedangkan mengenai subjek hukum perjanjian sendiri telah ditegaskan bahwa perjanjian timbul disebabkan oleh adanya hubungan hukum kekayaan antara dua orang atau lebih. Pendukung perjanjian sekurang-kurangnya harus ada dua orang tertentu. masing-masing orang itu menduduki tempat yang berbeda. Satu orang menjadi pihak kreditur dan seorang lagi pihak debitur itu lah yang menjadi subjek perjanjian. Kreditur mempunyai hak atas prestasi dan debitur wajib memenuhi pelaksanaan prestasinya. Prestasi adalah suatu yang wajib harus dipenuhi dalam setiap perikatan, prestasi merupakan isi daripada perikatan, apabila debitur tidak memenuhi prestasi sebagaimana yang telah ditentukan dalam perjanjian maka ia dikatakan wanprestasi.

Kata wanprestasi berasal dari bahasa Belanda, yang artinya prestasi buruk. Menurut Kamus Hukum, wanprestasi berarti kelalaian, kealpaan, cidera janji, tidak menepati kewajibannya dalam perjanjian. Adapun yang dimaksud wanprestasi adalah suatu keadaan yang dikarenakan kelalaian atau kesalahannya, debitur tidak dapat memenuhi prestasi seperti yang telah ditentukan dalam perjanjian dan bukan dalam keadaan memaksa adapun yang menyatakan bahwa wanprestrasi adalah tidak memenuhi atau lalai melaksanakan kewajiban sebagaimana 
yang ditentukan dalam perjanjian yang dibuat antara kreditur dengan debitur Abdulhay, (2004:2).

Seorang debitur baru dikatakan wanprestasi apabila ia telah diberikan somasi oleh kreditur atau Juru Sita. Somasi itu minimal telah dilakukan sebanyak tiga kali oleh kreditur atau Juru sita. Apabila somasi itu tidak diindahkannya, maka kreditur berhak membawa persoalan itu ke pengadilan untuk memutuskan apakah debitur wanprestasi atau tidak.

Menurut pasal 1238 KUH Perdata yang menyatakan bahwa:

"Si berutang adalah lalai, apabila ia dengan surat perintah atau dengan sebuah akta sejenis itu telah dinyatakan lalai, atau demi perikatan sendiri, ialah jika ini menetapkan bahwa si berutang harus dianggap lalai dengan lewatnya waktu yang ditentukan".

Dari ketentuan pasal tersebut dapat dikatakan bahwa debitur dinyatakan wanprestasi apabila sudah ada somasi (in gebreke stelling). Adapun bentuk-bentuk somasi menurut pasal 1238 KUH Perdata yang terdapat dalam buku Subekti, (2002:7-8) adalah:

1) Surat perintah

Surat perintah tersebut berasal dari hakim yang biasanya berbentuk penetapan. Dengan surat penetapan ini juru sita memberitahukan secara lisan kepada debitur kapan selambatlambatnya dia harus berprestasi. Hal ini biasa disebut "exploit juru Sita"

2) Akta sejenis

Akta ini dapat berupa akta dibawah tangan maupun akta notaris.

3) Tersimpul dalam perikatan itu sendiri
Maksudnya sejak pembuatan perjanjian, kreditur sudah menentukan saat adanya wanprestasi.

Dalam perkembangannya, suatu somasi atau teguran karena debitur yang melalaikan kewajibannya dapat dilakukan secara lisan, akan tetapi untuk mempermudah pembuktian dihadapan hakim apabila masalah tersebut berlanjut ke pengadilan maka sebaiknya diberikan peringatan secara tertulis (Sudarsono, 2007:9). Dalam keadaan tertentu somasi tidak diperlukan untuk dinyatakan bahwa seorang debitur melakukan wanprestasi yaitu dalam hal adanya batas waktu dalam perjanjian (fatal termijn), prestasi dalam perjanjian berupa tidak berbuat sesuatu, debitur mengakui dirinya wanprestasi. Debitur yang wanprestasi kepadanya dapat dijatuhkan sanksi, berupa kewajiban membayar kerugian yang dialami kreditur, pembatalan perjanjian, peralihan resiko, dan membayar biaya perkara bila sampai diperkarakan secara hukum di pengadilan.

Salah satu contoh kasus yang terjadi di Bandar Lampung pada tahun 2018 terjadi gugatan terhadap PT. Ghalaz Sukses Perkasa Bandar Lampung antara Juni Ramadita adalah konsumen PT. Ghalaz Sukses Perkasa, konsumen dalam hal ini adalah calon pembeli rumah, perumahan tersebut bernama perumahan griya sentra pesona 4 bahwa tanggal 26 maret menyerahkan boking fee sebesar Rp.2.000.000 (dua juta rupiah ) kemudian tanggal 26 april melakukan pembayaran uang muka tambahan sebesar Rp. 19.500.000 (sembilan belas juta lima ratus ribu rupiah) kemudian rumah yang di rencanakan oleh PT. Ghalaz Sukses Perkasa mengalami masalah dalam pembangunannya, sehingga penggugat mengundurkan diri dan di buat perjanjian 
pada tanggal 5 agustus 2016 antara PT. Ghalaz Sukses Perkasa dan di sepakati membuat perjanjian untuk mengembalikan dana kerugian sebesar Rp.30.000.000 (tiga puluh juta rupiah ) akan tetapi sampai batas waktu tanggal 23 Mei 2017 yang di sepakati pihak PT. Ghalaz Sukses Perkasa tidak kunjung mengembalikan uang tersebut kemudian korban mengajukan gugatan Wanprestasi ke Pengadilan Negeri Kelas 1A Tanjung Karang (Studi Putusan Nomor 02/Pdt.G/2018/PN.Tjk).

Untuk memahami lebih jelas tentang wanprestasi yang dilakukan oleh PT. Ghalaz Sukses Perkasa, maka penulis tertarik untuk melakukan penelitian yang dituangkan dalam bentuk skripsi dengan judul "Analisis Tentang Tanggungjawab PT. Ghalaz Sukses Perkasa Bandar Lampung Terkait Wanprestasi dalam Perjanjian Jual Beli Perumahan (Studi Putusan Nomor 02/Pdt.G/2018/PN.Tjk)."

Berdasarkan uraian latar belakang diatas,yang menjadi permasalahan dalam penelitian adalah:

1. Apa yang Menjadi Faktor Penyebab Terjadinya Wanprestasi dalam Perjanjian PT. Ghalaz Sukses Perkasa Bandar Lampung terhadap kreditur?

2. Bagaimanakah Pertanggungjawaban PT. Ghalaz Sukses Perkasa Bandar Lampung terhadap kreditur berdasarkan putusan Nomor 02/Pdt.G/2018/PN.Tjk ?

3. Bagaimana pelaksanaan hak dan kewajiban PT. Ghalaz Sukses Perkasa Bandar Lampung terhadap kreditur berdasarkan putusan Nomor 02/Pdt.G/2018/PN.Tjk?

Metode penelitian ini digunakan untuk menjawab permasalahan dan penelitian penulis ini adalah dengan menggunakan dua (2) pendekatan yuridis normatif dan pendekatan empiris. Pendekatan yuridis normatif yaitu pendekatan dengan cara menelaah berbagai macam peraturan perundang-undangan, teori-teori, dan literatur yang erat hubungannya dengan permasalahan yang akan dibahas. Pendekatan yuridis empiris yaitu dengan meneliti dan mengumpulkan data primer yang diperoleh secara langsung melalui wawancara dengan responden atau narasumber yang berhubungan dengan permasalahan yang akan di bahas dalam penelitian ini dan data sekunder diperoleh dengan cara studi kepustakaan.

\section{PEMBAHASAN}

\section{A. Faktor Penyebab Terjadinya Wanprestasi dalam Perjanjian PT. Ghalaz Sukses Perkasa Bandar Lampung terhadap kreditur.}

Dalam Pasal 1457 Kitab UndangUndang Hukum Perdata disebutkan bahwa jual beli adalah suatu perjanjian, dengan mana pihak yang satu mengikatkan dirinya untuk menyerahkan suatu kebendaan, dan pihak yang lain untuk membayar harga yang telah dijanjikan. Berdasarkan rumusan di dalam Pasal 1457 Kitab Undang-Undang Hukum Perdata tersebut, maka jual beli merupakan suatu perjanjian di mana pihak yang satu atau penjual mengikatkan dirinya untuk menyerahkan suatu benda, sedangkan pihak yang lainnya atau pembeli mengikatkan dirinya untuk membayar harga dari benda tersebut sebesar yang telah disepakati bersama.

Menurut bapak Syari Adami selaku Hakim Pada Pengadilan Negeri Kelas A Tajung Karang mengatakan bahwa faktofaktor penyebab terjadinya Wanprestasi disebabkan oleh sebab-sebab sebagai berikut: 
1. Kesengajaan atau kelalaian debitur itu sendiri.

Unsur kesengajaan ini, timbul dari pihak itu sendiri. Jika ditinjau dari wujud-wujud wanprestasi, maka faktornya adalah:

a. Tidak memiliki itikad baik, sehingga prestasi itu tidak dilakukan sama sekali;

b. Faktor keadaan yang bersifat general;

c. Tidak disiplin sehingga melakukan prestasi tersebut ketika sudah kedaluwarsa;

d. Menyepelekan perjanjian.

2. Adanya keadaan memaksa (overmacht).

Biasanya, overmacht terjadi karena unsur ketidak sengajaan yang sifatnya tidak diduga, contohnya seperti kecelakaan dan bencana alam.

Ada empat akibat adanya wanprestasi, yaitu sebagai berikut:

a. Perikatan tetap ada;

b. Debitur harus membayar ganti rugi kepada kreditur (Pasal 1243 KUH Perdata);

c. Beban resiko beralih untuk kerugian debitur, jika halangan itu timbul setelah debitur wanprestasi, kecuali bila ada kesenjangan atau kesalahan besar dari pihak kreditur. Oleh karena itu, debitur tidak dibenarkan untuk berpegang pada keadaan memaksa;

d. Jika perikatan lahir dari perjanjian timbal balik, kreditur dapat membebaskan diri dari kewajibannya memberikan kontra prestasi dengan menggunakan Pasal 1266 KUH Perdata.
Selanjutnya bapak Syari Adami menambahkan akibat wanprestasi yang dilakukan debitur, dapat menimbulkan kerugian bagi kreditur, sanksi atau akibatakibat hukum bagi debitur yang wanprestasi ada 4 macam, yaitu:

1) Debitur diharuskan membayar gantikerugian yang diderita oleh kreditur (Pasal 1243 Kitab Undang-Undang Hukum Perdata);

2) Pembatalan perjanjian disertai dengan pembayaran ganti-kerugian (Pasal 1267 Kitab Undang-Undang Hukum Perdata);

3) Peralihan risiko kepada debitur sejak saat terjadinya wanprestasi (Pasal 1237 ayat 2 Kitab Undang-Undang Hukum Perdata);

4) Pembayaran biaya perkara apabila diperkarakan di muka hakim (Pasal 181 ayat 1 Kitab Undang-Undang Hukum Perdata).

Kemudian menurut bapak Jhony Butar Butar Selaku Ketua Majelis Hakim yang mengadili Perkara Nomor 2/pdt.G/2018/PNTJK menmbahkan bahwa Dalam hal debitur tidak memenuhi kewajibannya atau tidak memenuhi kewajibannya sebagaimana mestinya dan tidak dipenuhinya kewajiban itu karena ada unsur salah padanya, maka seperti telah dikatakan bahwa ada akibat-akibat hukum yang atas tuntutan dari kreditur bisa menimpa dirinya. Sebagaimana yang disebutkan dalam Pasal 1236 Kitab Undang-Undang Hukum Perdata dan Pasal 1243 Kitab Undang-Undang Hukum Perdata dalam hal debitur lalai untuk memenuhi kewajiban perikatannya kreditur berhak untuk menuntut penggantian kerugian, yang berupa ongkos-ongkos, kerugian dan bunga. Selanjutnya Pasal 1237 Kitab Undang-Undang Hukum 
Perdata mengatakan, bahwa sejak debitur lalai, maka resiko atas objek perikatan menjadi tanggungan debitur. Yang ketiga adalah bahwa kalau perjanjian itu berupa perjanjian timbal balik, maka berdasarkan Pasal 1266 Kitab Undang-Undang Hukum Perdata sekarang kreditur berhak untuk menuntut pembatalan perjanjian, dengan atau tanpa disertai dengan tuntutan ganti rugi.

Berdasarkan uraian di atas dapat di simpukan bahwa fakto-faktor penyebab terjadinya Wanprestasi disebabkan oleh kesengajaan atau kelalaian debitur itu sendiri unsur kesengajaan ini, timbul dari pihak itu sendiri. Jika ditinjau dari wujudwujud wanprestasi, maka faktornya seperti tidak memiliki itikad baik, sehingga prestasi itu tidak dilakukan sama sekali, faktor keadaan yang bersifat general, Tidak disiplin sehingga melakukan prestasi tersebut ketika sudah kedaluwarsa, Menyepelekan perjanjian. Kemudian fakor penyebab wanprestasi lainya yaitu adanya keadaan memaksa (overmacht). Biasanya, overmacht terjadi karena unsur ketidak sengajaan yang sifatnya tidak diduga. Contohnya seperti kecelakaan dan bencana alam.

\section{B. Pertanggungjawaban PT. Ghalaz Sukses Perkasa Bandar Lampung terhadap kreditur.}

Menurt bapak Jhony Butar Butar Selaku hakim pada Pngadilan Negri Kelas I A Tanjung Karang bahwa Pertanggungjawaban PT. Ghalaz Sukses Perkasa Bandar Lampung terhadap kreditur berdasarkan putusan Nomor 02/Pdt.G/2018/PN.Tjk mengatakan bahwa dalam pertimbangan majelis maksud dan tujuan gugatan penggugat pada pokoknya ialah Wanprestasi, dimana tergugat sebelumnya sepakat mengembalikan uang booking fee/uang muka/cicilan rumah karena rumah yang direncanakan mengalami masalah dalam pembangunan maka penggugat meminta mengembalikan uangnya.

Hal terssebut berdasrkan dalam Pasal 1236 Kitab Undang-Undang Hukum Perdata dan 1243 Kitab Undang-Undang Hukum Perdata dalam hal debitur lalai untuk memenuhi kewajiban perikatannya kreditur berhak untuk menuntut penggantian kerugian, yang berupa ongkos-ongkos, kerugian dan bunga. Selanjutnya Pasal 1237 Kitab UndangUndang Hukum Perdata mengatakan, bahwa sejak debitur lalai, maka resiko atas objek perikatan menjadi tanggungan debitur. Yang ketiga adalah bahwa kalau perjanjian itu berupa perjanjian timbal balik, maka berdasarkan Pasal 1266 Kitab Undang-Undang Hukum Perdata sekarang kreditur berhak untuk menuntut pembatalan perjanjian, dengan atau tanpa disertai dengan tuntutan ganti rugi. Dalam hal ini PT Ghalaz Sukses Perkasa wajib mentaati putusan Pengadilan Negeri tingkat pertama apabila tidak ada upaya lainnya dari Tergugat yaitu banding.

Kemudian Bapak Jhony Butar Butar menambahkan berkaitan perjanjian yang di buat antara kedua belah pihak itu sah menurut hukum dalam pasal 1338 KUHPerdata menyatakan semua persetujuan yang dibuat secara sah berlaku sebagai undang-undang bagi mereka yang membuatntya. persetujuan-persetujuan itu tidak dapat ditarik kembali selain dengan sepakat dengan kedua belah pihak atau karena alasan-alasan yang oleh undangundang dinyatakan cukup untuk itu. persetujuan harus dilaksanakan dengan itikad baik. Dengan istilah semua maka pembentuk undang-undang menunjukan bahwa perjanjin yang dimaksud bukanlah 
hanya semata-mata perjanjian bernama, tetapi juga meliputi perjanjian yang tidak bernama. didalam istilah semuaitu terkandung suatuasas yang di kenal dengan asas partij autonomie pasal 1338 KUHPerdata ini harus juga dalam kaitanya dengan pasal 1319 KUHPerdata.

\section{PUTUSAN}

Nomor 2/Pdt.G/2018PN.Tjk

Berdasarkan hasil penelitian di Pengadilan Negeri Kelas IA Tanjung Karang Bapak Jhony Butar-Butar selaku Hakim Ketua yang memeriksa dan mengadili perkara tersebut pada pengadilan tingkat pertama yang diperiksa dengan cara pemeriksaan biasa menjatuhkan putusan sebagai berikut:

1. Nama : Juni Ramadita, berkedudukan di Perumnas Griya Nusantara Kelurahan Menggala Selatan, Kecamatan Menggala, Kabupaten Tulang Bawang Provinsi Lampung.

2. Eri Rilta berkedudukan di Jalan Karya Bakti Kelurahan Menggala Selatan, Kecamatan Menggala, Kabupaten Tulang Bawang Provinsi Lampung. Kedua-duanya memberikan kuasa kepada David Sihombing, S.H. sebagai penggugat.

\section{Melawan}

Direksi PT. Ghalas Sukses Perkasa beralamat di Jalan P. Tirtayasa Ruko Nusantara No. 7-8 Sukabumi, Bandar Lampung, Provinsi Lampung, sebagai tergugat.

\section{Posisi Kasus}

Bahwa penggugat adalah konsumen tergugat dalam hal ini calon pembeli rumah, perumahan tersebut bernama Perumahan Griya Sentra Pesona IV (GSP IV). Yang beralamat di jalan Kebersihan,
Keluranan Sukadanaham, Bandar Lampung dan para penggugat telah menggunakan uang yang disebut dengan booking fee/uang muka/cicilan. Penyerahan booking fee sebesar Rp. 2.000.000,- tanggal 26 Maret 2016 kemudian menyerahkan uang muka sebesar Rp. 19.500.000,- kemudian Tanggal 26 April melakukan tambahan uang muka Rp. 8.500.000,-. Namun rumah yang direncanakan mengalami masalah dalam pembangunannya dan tergugat berjanji apabila sampai tanggal 5 Agustus 2016 berdasarkan kesepakatan akan memulangkan seluruh uang tersebut. Tetapi sampai dengan gugatan diajukan belum juga memulangkan kekurangan Rp. 15.000.000,- kepada penggugat. Sehingga penggugat melakukan upaya hukum kPengadilan Negeri Kelas IA Tanjung Karang.

\section{Mengadili}

1. Mengabulkan gugatan penggugat seluruhnya

2. Menyatakan tergugat telah melakukan Wan Prestasi/ingkar janji kepada para penggugat.

3. Menghukum tergugat untuk memenuhi kewajibannya dengan membayar secara tunai dan seketika kepada penggugat yang masing-masing sebesar Rp. 15.000.000,- (Lima Belas Juta Rupiah).

4. Menghukum tergugat untuk membayar perkara ini Rp. 391.000,- (Tiga Ratus Sembilan Puluh Satu Ribu Rupiah).

Menurt bapak Jhony Butar Butar Selaku hakim pada Pngadilan Negri Kelas I A Tanjung Karang bahwa Pertanggungjawaban PT. Ghalaz Sukses Perkasa Bandar Lampung terhadap kreditur berdasarkan putusan Nomor 
02/Pdt.G/2018/PN.Tjk mengatakan bahwa dalam pertimbangan majelis maksud dan tujuan gugatan penggugat pada pokoknya ialah Wanprestasi, dimana tergugat sebelumnya sepakat mengembalikan uang booking fee/uang muka/cicilan rumah karena rumah yang direncanakan mengalami masalah dalam pembangunan maka penggugat meminta mengembalikan uangnya.

Hal terssebut berdasrkan dalam Pasal 1236 Kitab Undang-Undang Hukum Perdata dan 1243 Kitab Undang-Undang Hukum Perdata dalam hal debitur lalai untuk memenuhi kewajiban perikatannya kreditur berhak untuk menuntut penggantian kerugian, yang berupa ongkos-ongkos, kerugian dan bunga. Selanjutnya Pasal 1237 Kitab UndangUndang Hukum Perdata mengatakan, bahwa sejak debitur lalai, maka resiko atas objek perikatan menjadi tanggungan debitur. Yang ketiga adalah bahwa kalau perjanjian itu berupa perjanjian timbal balik, maka berdasarkan Pasal 1266 Kitab Undang-Undang Hukum Perdata sekarang kreditur berhak untuk menuntut pembatalan perjanjian, dengan atau tanpa disertai dengan tuntutan ganti rugi. Dalam hal ini PT Ghalaz Sukses Perkasa wajib mentaati putusan Pengadilan Negeri tingkat pertama apabila tidak ada upaya lainnya dari Tergugat yaitu banding.

Kemudian Bapak Jhony Butar Butar menambahkan berkaitan perjanjian yang di buat antara kedua belah pihak itu sah menurut hukum dalam pasal 1338 KUHPerdata menyatakan semua persetujuan yang dibuat secara sah berlaku sebagai undang-undang bagi mereka yang membuatntya. persetujuan-persetujuan itu tidak dapat ditarik kembali selain dengan sepakat dengan kedua belah pihak atau karena alasan-alasan yang oleh undang- undang dinyatakan cukup untuk itu. persetujuan harus dilaksanakan dengan itikad baik. dengan istilah semua maka pembentuk undang-undang menunjukan bahwaperjanjin yang dimaksud bukanlah hanya semata-mata perjanjian bernama, tetapi juga meliputi perjanjian yang tidak bernama. didalam istilah semuaitu terkandung suatuasas yang di kenal dengan asas partij autonomie pasal 1338 KUHPerdata ini harus juga dalam kaitanya dengan Pasal 1319 KUHPerdata.

Selajutnya bapak Syahri Adami istilah Perjanjian secara sah pembentuk undangundnag menunjukan bahwa pembuatan perjanjian harus memenuhi syarat-syarat yang ditentukan. semua persetujuan yang dibuat menurut hukum secara sah ( Pasal 1320 KUHPerdata) adalah mengikat sebagai undnag-undang terhadap para pihak. disini tersimpul realisasi asas kepastian hukum. Pasal 1338 ayat (1) KUHPerdata menunjukan kekuatan kedudukan kreditur dan sebagai konsekunsinya perjanjian itu tidak dapat ditarik kembali secara sepihak. namun kedudukan ini diimbangi dengan Pasal 1338 ayat (3) KUHPerdata yang mengatakan bahwa perjanjian harus dilaksanakan dengan itikad baik. hal ini memberi perlindungan kepada debitur dan kedudukan antara kreditur dan debitur menjadi seimbang. ini merupakan realisasi dari asas keseimbangan. dalam hukum perjanjian mengenal beberapa asas penting, yang merupakan dasar kehendak pihakpihak dalam mencapai tujuan.

Berdasarkan uraian tersebut di atas dapat disimpulkan bahwa Pertanggungjawaban PT. Ghalaz Sukses Perkasa Bandar Lampung terhadap kreditur berdasarkan putusan Nomor 02/Pdt.G/2018/PN.Tjk dalam pertimbangan majelis maksud dan tujuan 
gugatan penggugat pada pokoknya ialah Wanprestasi, dimana tergugat sebelumnya sepakat mengembalikan uang booking fee/uang muka/cicilan rumah karena rumah yang direncanakan mengalami masalah dalam pembangunan maka penggugat meminta mengembalikan uangnya, dan dalam putusan pengadilan tingkat pertama mengabulkan gugata untuk sluruhnya karna perjanjian kedua belah pihak sah menuruhhukum sehingga tergugat dalam putusah mengembalikan uang tersebut apabia tidak ada upaya banding.

Berkaitan perjanjian yang di buat antara kedua belah pihak itu sah menurut hukum dalam Pasal 1338 KUHPerdata menyatakan semua persetujuan yang dibuat secara sah berlaku sebagai undangundang bagi mereka yang membuatntya. persetujuan-persetujuan itu tidak dapat ditarik kembali selain dengan sepakat dengan kedua belah pihak atau karena alasan-alasan yang oleh undang-undang dinyatakan cukup untuk itu.

\section{Pelaksanaan hak dan kewajiban PT. Ghalaz Sukses Perkasa Bandar Lampung terhadap kreditur.}

Karena wanprestasi mempunyai akibat-akibat yang begitu penting, maka harus ditetapkan lebih dahulu apakah si berutang melakukan wanprestasi atau lalai, dan kalau hal itu disangkal olehnya, maka harus dibuktikan di muka hakim. Pengajuan ke pengadilan tentang wanprestasi dimulai dengan adanya somasi yang dilakukan oleh seorang juru sita dari pengadilan, yang membuat proses verbal tentang pekerjaannya itu, atau juga cukup dengan surat tercatat atau surat kawat, asal saja jangan sampai dengan mudah dimungkiri oleh si berutang. Kadangkadang juga tidak mudah untuk mengatakan bahwa seseorang lalai atau alpa, karena seringkali juga tidak dijanjikan dengan tepat kapan sesuatu pihak diwajibkan melakukan wanprestasi yang dijanjikan.

Berdarkan wawancara denagan bapak Zuhardi Selaku Hakim Pada Pengadilan Negeri Kelas I A Tanjung Karang mengatakan bahwa terkait pelaksanaan dan kewajibat para pihak yang bersengketa di pengadilan terkait Debitur dan Kreditur ya ng meakukan wanprestasi, kreditur harus sebisa mungkin membuktikan bahwa lawannya (debitur) tersebut telah melakukan wanprestasi, bukan overmacht. Begitu pula dengan debitur, debitur harus meyakinkan hakim jika kesalahan bukan terletak padanya dengan pembelaan seperti berikut:

1. Overmacht;

2. Menyatakan bahwa kreditur telah melepaskan haknya; dan

3. Kelalaian kreditur.

Jika debitur tidak terbukti melakukan wanprestasi, maka kreditur tidak bisa menuntut apa-apa dari debitur tersebut. Tetapi jika yang diucapkan kreditur di muka pengadilan terbukti, maka kreditur dapat menuntut:

1. Menuntut hak pemenuhan perjanjian;

2. Menuntut hak pemenuhan perjanjian berikut dengan ganti rugi sesuai Pasal 1246 KUHPerdata yang menyatakan, "biaya, ganti rugi dan bunga, yang boleh dituntut kreditur, terdiri atas kerugian yang telah dideritanya dan keuntungan yang sedianya dapat diperolehnya". Berdasarkan Pasal 1246 KUHPerdata tersebut, dalam wanprestasi, penghitungan ganti rugi harus dapat diatur berdasarkan jenis dan jumlahnya secara rinci seperti kerugian kreditur, keuntungan yang akan diperoleh sekiranya perjanjian 
tesebut dipenuhi dan ganti rugi bunga (interest).
a. Ganti biaya yaitu mengganti pengeluranan yang dikeluarkan kreditur;
b. Ganti rugi yaitu mengganti barang- barang rusak; dan
c. Ganti bunga yaitu mengganti keuntungan yang seharusnya didapat.

Selanjutnya bapak Zuhardi menambahkan dalam hal pembatalan perjanjian, banyak pendapat yang mengemukakan bahwa pembatalan ini dilakukan oleh hakim dengan mengeluarkan putusan yang bersifat declaratoir. Hakim juga mempunyai suatu kekuasaan yang bernama "discretionair", artinya ia berwenang untuk menilai wanprestasi debitur. Apabila kelalaian itu dianggapnya terlalu kecil, hakim berwenang untuk menolak pembatalan perjanjian meski ganti rugi yang diminta harus dituluskan.

1) Pembatalan perjanjian disertai ganti rugi;

2) Meminta/ menuntut ganti rugi saja.

Dan hak-hak yang dituntut oleh kreditur dicantumkan pada bagian petitum dalam surat gugatan. Jika debitur tidak bisa membuktikan bahwa ia tidak melakukan wanprestasi tersebut, maka biaya perkara seluruhnya dibayar oleh debitur.

Berdasarkan uraian di atas dapat di simpukan bahwa Pelaksanaan hak dan kewajiban PT. Ghalaz Sukses Perkasa Bandar Lampung terhadap kreditur berdasarkan putusan Nomor 02/Pdt.G/2018/PN.Tjk, kreditur harus sebisa mungkin membuktikan bahwa lawannya (debitur) tersebut telah melakukan wanprestasi, bukan overmacht.
Begitu pula dengan debitur, debitur harus meyakinkan hakim jika kesalahan bukan terletak padanya dengan pembelaan seperti Overmach, Menyatakan bahwa kreditur telah melepaskan haknya dan Kelalaian kreditur. Jika debitur tidak terbukti melakukan wanprestasi, maka kreditur tidak bisa menuntut apa-apa dari debitur tersebut. Tetapi jika yang diucapkan kreditur di muka pengadilan terbukti, maka kreditur dapat menuntut hak pemenuhan perjanjian, menuntut hak pemenuhan perjanjian berikut dengan ganti rugi sesuai Pasal 1246 KUHPerdata yang menyatakan, "biaya, ganti rugi dan bunga, yang boleh dituntut kreditur, terdiri atas kerugian yang telah dideritanya dan keuntungan yang sedianya dapat diperolehnya".

Berdasarkan Pasal 1246 KUHPerdata tersebut, dalam wanprestasi, penghitungan ganti rugi harus dapat diatur berdasarkan jenis dan jumlahnya secara rinci seperti kerugian kreditur, keuntungan yang akan diperoleh sekiranya perjanjian tesebut dipenuhi dan ganti rugi bunga (interest), ganti biaya yaitu mengganti pengeluranan yang dikeluarkan kreditur, ganti rugi yaitu mengganti barang-barang rusak; dan ganti bunga yaitu mengganti keuntungan yang seharusnya didapat.

\section{PENUTUP}

\section{A. Kesimpulan}

Berdasarkan hasil Penelitian dan pembahasan yag telah di uraikan pada bab terdahulu, maka dapat ditarik kesimpulan sebagai berikut :

1. Fakto-Faktor penyebab terjadinya Wanprestasi disebabkan oleh kesengajaan atau kelalaian debitur itu sendiri unsur kesengajaan ini, timbul dari pihak itu sendiri. Jika ditinjau dari wujud-wujud wanprestasi, maka faktornya seperti tidak memiliki itikad 
baik, sehingga prestasi itu tidak dilakukan sama sekali, Faktor keadaan yang bersifat general, tidak disiplin sehingga melakukan prestasi tersebut ketika sudah kedaluwarsa, menyepelekan perjanjian. Kemudian fakor penyebab wanprestasi lainya yaitu adanya keadaan memaksa (overmacht). Biasanya, overmacht terjadi karena unsur ketidaksengajaan yang sifatnya tidak diduga. contohnya seperti kecelakaan dan bencana alam.

2. Pertanggungjawaban PT. Ghalaz Sukses Perkasa Bandar Lampung terhadap kreditur berdasarkan putusan Nomor 02/Pdt.G/2018/PN.Tjk diputus oleh majelis Hakim mengabulkan gugatan penggugat terhadap tergugat yaitu Pasal 1338 KUHPerdata wanpretasi. Terbukti dipersidangan bahwa tergugat tergugat sebelumnya sepakat mengembalikan uang booking fee/uang muka/cicilan rumah, karena rumah yang direncanakan mengalami masalah dalam pembangunan. Penggugat meminta pengambalian atas uangnya, dan dalam putusan pengadilan tingkat pertama mengabulkan gugatan untuk seluruhnya karena perjanjian kedua belah pihak sah menurut hukum.

3. Pelaksanaan hak dan kewajiban PT. Ghalaz Sukses Perkasa Bandar Lampung terhadap kreditur berdasarkan putusan Nomor 02/Pdt.G/2018/PN.Tjk, kreditur harus sebisa mungkin membuktikan bahwa lawannya (debitur) tersebut telah melakukan wanprestasi, bukan overmacht. Begitu pula dengan debitur, debitur harus meyakinkan hakim jika kesalahan bukan terletak padanya dengan pembelaan seperti Overmach, menyatakan bahwa kreditur telah melepaskan haknya dan kelalaian kreditur. Jika debitur tidak terbukti melakukan wanprestasi, maka kreditur tidak bisa menuntut apa-apa dari debitur tersebut. Tetapi jika yang diucapkan kreditur di muka pengadilan terbukti, maka kreditur dapat menuntut hak pemenuhan perjanjian, menuntut hak pemenuhan perjanjian berikut dengan ganti rugi sesuai Pasal 1246 KUHPerdata yang menyatakan, "biaya, ganti rugi dan bunga, yang boleh dituntut kreditur, terdiri atas kerugian yang telah dideritanya dan keuntungan yang sedianya dapat diperolehnya".

\section{B. Saran}

1. Hendaknya peraturan yang terkait dengan perumahan yang memberikan perlindungan terhadap pengembang perumahan dalam Pasal 130 huruf (a) dan (c) Undang-Undang Nomor 1 Tahun 2011 tentang Perumahan dan Kawasan Permukiman lebih tegas dan untuk peraturan yang terkait dengan perumahan yang memberikan perlindungan terhadap konsumen, hendaknya lebih baik dalam hal memberikan kepastian hukum untuk meminimalisir kerugian yang akan diderita konsumen.

2. Hendaknya tanggung jawab yang dibebankan pada pelaku usaha tidak hanya tanggung jawab mutlak (strict product liability) sebagaimana diatur dalam Pasal 151 Undang-Undang Nomor 1 Tahun 2011 tentang Perumahan dan Kawasan Permukiman, Pasal 8 ayat (1) huruf (f) dan Pasal 62 ayat (1) Undang-Undang No. 8 tahun 1999 tentang Perlindungan Konsumen dan Contractual liability (tanggung jawab 
yang didasarkan pada perjanjian) sebagaimana diatur dalam Pasal 134 Undang-Undang Nomor 1 Tahun 2011 tentang Perumahan dan Kawasan Permukiman saja, agar pengembang dalam melakukan penyelenggaraan pembangunan perumahan lebih baik.

3. Hendaknya dalam penyelesaian sengketa konsumen terlebih dahulu agar diselesaikan dengan cara musyawarah mufakat atau secara damai, karena ini merupakan amanat Pasal 147 Undang-Undang Nomor 1 Tahun 2011 tentang Perumahan dan Kawasan Permukiman. Penyelesaian selanjutnya dapat dilakukan melalui di luar pengadilan (non litigasi) atau melalui peradilan umum (litigasi).

\section{DAFTAR PUSTAKA}

\section{A. Buku}

Abdulhay, Marhainis, 2004, Hukum Perdata Materi, Pradnya Paramita, Jakarta.

Subekti, 2002, Pokok-Pokok Hukum Perdata, Intermas, Jakarta.

Sudarsono, 2007, Kamus Hukum, Rineka Cipta, Jakarta.

Tami Rusli, 2012, Hukum Perjanjian Yang Berkembang Di Indonesia, Anugrah Utama Raharja, Bandar lampung.

Yahya Harahap 1986. Segi-Segi Hukum Perjanjian, Alumni, Bandung.

\section{B. Perundang-Undangan}

Kitab Undang-Undang Hukum Perdata (KUHPdt).

Kitab Undang-Undang Hukum Acara Perdata $(H I R-R B G)$. 